\title{
GAMBARAN HITOLOGI GINJAL TIKUS PUTIH (WISTAR) SETELAH PEMBERIAN RIFAMPISIN
}

\author{
${ }^{1}$ Indah S Mappa \\ ${ }^{2}$ Carla Kairupan \\ ${ }^{3}$ Lily Loho \\ ${ }^{1}$ Bagian Patologi Anatomi \\ 2Email: indah.mappa@yahoo.com
}

\begin{abstract}
Rifampicyn a bactericidal antibiotic drug of the rifamycin group. The drug is made from semisynthetic compound derived from Amycolatopsis rifamycinica (formerly known as Amycolatopsis mediterranei and Streptomyces mediterranei). Rifampicyn dose of $600 \mathrm{mg} /$ day in humans can cause side effects such as kidney renal insufficiency, acute renal failure, urine output, and the orange-red. This study a imsto look at the white rat renal histological (Wistar) after administration of rifampin. This research was conducted at the Research Laboratory of Integrated Pathology Faculty of Medicine University of Sam Ratulangi Manado. Study using 10 rats (Wistar) consisting of 3 treatment groups. The results showed that the use of rifampicyn at a dose of $5 \mathrm{mg}$ in rats (Wistar) showed vacuole-vacuole in the renal tubular cells, where as the use of rifampicyn at a dose of $8 \mathrm{mg}$ in rats (Wistar) causes acute tubular necrosis.
\end{abstract}

Keywords: Kidney White Rat (Wistar), rifampicyn.

\begin{abstract}
Abstrak: Rifampisin adalah obat antibiotik bakterisida dari kelompok rifamycin. Obat ini terbuat dari senyawa semisintetik yang berasal dari Amycolatopsis rifamycinica (sebelumnya dikenal sebagai Amycolatopsis mediterranei dan Streptomyces mediterranei). Rifampisin dosis $600 \mathrm{mg} /$ hari pada manusia dapat menyebabkan efek samping terhadap ginjal berupa insufiensi ginjal, gagal ginjal akut, dan pengeluaran urin yang berwarna oranye-kemerahan. Penelitian ini bertujuan untuk melihat gambaran histologi ginjal tikus putih (Wistar) setelah pemberian rifampisin. Penelitian ini dilakukan di Laboratorium Riset Terpadu Patologi Anatomi Fakultas Kedokteran Universitas Sam Ratulangi Manado. Penelitian mengunakan 10 ekor tikus (Wistar) terdiri dari 3 kelompok perlakuan. Hasil penelitian menunjukkan bahwa pengunaan rifampisin dengan dosis $5 \mathrm{mg}$ pada tikus (Wistar) menunjukkan adanya vakuolavakuola di dalam sel tubulus ginjal, sedangkan pengunaan rifampisin dengan dosis $8 \mathrm{mg}$ pada tikus (Wistar) menyebabkan terjadinya nekrosis tubular akut.
\end{abstract}

Kata Kunci: Ginjal Tikus Putih (Wistar), Rifampisin.

Rifampisin adalah obat antibiotik bakterisida dari kelompok rifamycin. Obat ini terbuat dari senyawa semisintetik yang berasal dari Amycolatopsis rifamycinica (sebelumnya dikenal sebagai Amycolatopsis mediterranei dan Streptomyces mediterranei). Rifampisin yang diproduksi sejak tahun 1959, juga dikenal sebagai rifaldazine, R/AMP, rofact (di Kanada), dan rifampisin di Amerika
Serikat. Ada berbagai jenis rifamycins berdasarkan sumber, namun bentuk rifampisin, dengan 4-metil-1-piperazinaminyl merupakan kelompok yang paling efektif secara klinis. ${ }^{1,2,3}$

Rifampisin merupakan senyawa bentuk padat berwarna merah dan sebagian kecil yang masuk dalam cairan tubuh menyebabkan warna merah pada urin (pada 
tingkat lebih rendah, juga keringat dan air mata) pengguna dalam beberapa jam setelah pemberian. Konsentrasi maksimal dalam darah menurun sekitar sepertiga ketika antibiotik diminum setelah makan. ${ }^{4}$

Rifampisin digunakan dalam pengobatan penyakit akibat sejumlah bakteri, namun paling dikenal untuk pengobatan penyakit yang disebabkan oleh $\mathrm{Myco-}$ bacterium, seperti tuberkulosis (TBC) dan penyakit Hansen. Rifampisin dapat digunakan sebagai monoterapi selama beberapa hari untuk profilaksis terhadap meningitis, namun resistensi berkembang dengan cepat selama pengobatan infeksi aktif yang panjang sehingga obat ini selalu digunakan terhadap infeksi aktif dalam kombinasi dengan antibiotik lain. ${ }^{5}$

Rifampisin $85 \%$ sampai 90\% dimetabolisme di hati dan sebagian besar dikeluarkan melalui saluran empedu. Rifampisin juga dapat menyebabkan peningkatan serum transaminase secara asimptomatik pada sebagian penderita sehingga mengalami efek kolestatik. Rifampisin bekerja sinergis dengan isoniazid. Efek samping yang paling sering terjadi yaitu di hati sehingga dapat menimbulkan ikterus dan peningkatan kadar enzim aspartat dan amino transaminase. Beberapa literatur menunjukkan bahwa selain efek samping terhadap hati, pemberian rifampisin dalam dosis berlebihan (diatas $600 \mathrm{mg} /$ hari) bisa menyebabkan efek samping terhadap ginjal.

\section{METODE PENELITIAN}

Penelitian ini merupakan penelitian eksperimental yang dilakukan di bagian Lab Riset Terpadu Fakultas Kedokteran Universitas Sam Ratulangi Manado. Pemeriksaan sampel dilakukan di Laboratorium Patologi Anatomi Fakultas Kedokteran Universitas Sam Ratulangi Manado. Penelitian dilaksanakan pada selama November 2011 - Februari 2012.

Subjek penelitian adalah tikus putih (Wistar) berjumlah 10 ekor yang dibagi dalam kelompok kontrol dan perlakuan. Berat tikus rata-rata 150-200 g dan gam- baran histologi ginjal dinilai berdasarkan struktur histologis ginjal.

\section{Alat dan Bahan:}

Pengambilan sampel: alat otopsi, botol untuk mengisi ginjal, Pemotretan: kamera, Pembuatan preparat: pinset, pisau, gunting, mikrotom, Pengamatan preparat: mikroskop cahaya, mikrofoto dan Fiksasi jaringan: Formalin 10\%, Dehidrasi: alkohol 70\%, 80\%, 90\%, 95\%, 100\%, Dealkoholisasi: xylol, Infiltrasi: paraffin, Perwarnaan: Hematoksilin Eosin, Preparat: kaca objek + kaca penutup, entelan.

\section{Prosedur Penelitian}

\section{Pemeliharaan tikus wistar}

Tikus wistar dipelihara dengan diberi makan pelet dan minum setiap hari selama penelitian berlangsung. Pada saat penelitian selesai, tikus wistar diterminasi kemudian diambil ginjalnya untuk pembuatan preparat.

\section{Penentuan dosis rifampisin}

Dosis rifampisin $600 \mathrm{mg} /$ hari sebagai dosis terapi pada manusia. Bila berat ratarata tikus wistar $=200 \mathrm{~g}$, maka rifampisin yang diberikan: konversi berat badan ratarata manusia dewasa (50 kg $=50.000$ gr) dibagi berat tikus wistar adalah 200g: 50.000 gr x $600 \mathrm{mg}=2,4$

$2 \times 2,4=4,8 \mathrm{mg} /$ hari dibulatkan menjadi 5 $\mathrm{mg} /$ hari pada kelompok B

$3 \times 2,4=7,2 \mathrm{mg} /$ hari dibulatkan menjadi 8 mg/hari pada kelompok C

\section{Perlakuan terhadap hewan uji}

Hewan uji terdiri dari 11 ekor tikus wistar yang dibagi dalam 3 kelompok. Semua tikus diberi makan pelet yang sama setiap hari selama perlakuan. Pembagian kelompok hewan uji adalah sebagai berikut: Kelompok A sebagai kontrol negatif, kelompok B sebagai kelompok perlakuan 1 yang diberikan rifampisin dosis $5 \mathrm{mg}$ / hari selama 7 hari dan kelompok $C$ sebagai kelompok perlakuan 2 yang di berikan rifampisin dosis $8 \mathrm{mg} / \mathrm{hari}$ 
selama 10 hari.

\section{Pengambilan sampel ginjal tikus putih (wistar)}

Setelah tikus wistar diterminasi, kedua ginjal diambil (ginjal kiri dan kanan), selanjutnya ginjal dimasukkan ke dalam larutan formalin $10 \%$ untuk difiksasi dan diberi label.

\section{Pengamatan secara makroskopik}

Dilakukan pengamatan terhadap ginjal tikus (Wistar), pemotretan, dan penimbangan, kemudian dilakukan pemotongan membujur. Sayatan dibuka dan diamati.

\section{HASIL PENELITIAN}

\section{Gambaran Makroskopik}

Gambaran makroskopik ginjal tikus putih (wistar) dinilai berdasarkan warna, konsistensi, dan berat kedua ginjal (ginjal kiri dan kanan). Berdasarkan hasil penelitian yang didapat, gambaran makroskopik ginjal tikus putih (wistar) menunjukkan perbedaan yang jelas pada warna yaitu pada kelompok kontrol negatif ginjal berwarna merah, sedangkan pada kelompok perlakuan B ginjal berwarna merah kepucatan dan pada kelompok perlakuan C ginjal berwarna merah kecoklatan.

\section{Gambaran Mikroskopik}

\section{Kelompok A (Kontrol negatif)}

Gambaran mikroskopik ginjal tikus putih (wistar) kelompok kontrol negatif yang hanya diberikan pelet dan minum selama 10 hari tampak sel-sel epitel tubulus normal. Pada bagian korteks tampak lebih gelap dibandingkan medula. Sitoplasma sel epitel tubulus homogen, berwarna merah muda dan jernih.

\section{Kelompok perlakuan B}

Gambaran mikroskopik ginjal tikus putih (wistar) setelah diberikan rifampisin dengan dosis $5 \mathrm{mg}$ selama 7 hari menunjukkan adanya sel- sel yang membengkak dan terdapat vakuola-vakuola di dalam sitoplasma.

\section{Kelompok perlakuan C}

Gambaran mikroskopik ginjal tikus putih (wistar) setelah pemberian rifampisin dengan dosis $8 \mathrm{mg}$ selama 10 hari. Tampak adanya sel-sel epitel tubulus yang mengalami nekrosis, terdapat pembengkakan sel dan adanya sel-sel di dalam lumen tubulus.

\section{BAHASAN}

Kerusakan yang terjadi pada ginjal, terutama bentuk cedera tubular, selain

Tabel. 1. Gambaran makroskopik ginjal tikus putih (wistar)

\begin{tabular}{|c|c|c|c|c|}
\hline $\begin{array}{l}\text { Kelompok } \\
\text { (gr) }\end{array}$ & Perlakuan & Warna & Konsistensi & Berat \\
\hline A1 & Hanya diberi pelet & Merah & Kenyal & 0,25 \\
\hline A2 & Hanya diberi pelet & Merah & Kenyal & 0,81 \\
\hline $\mathrm{B} 1$ & Rifampisin 5 mg selama 7 hari & Merah kepucatan & Kenyal & 0,26 \\
\hline $\mathrm{B} 2$ & Rifampisin 5 mg selama 7 hari & Merah kepucatan & Kenyal & 0,87 \\
\hline B3 & Rifampisin 5 mg selama 7 hari & Merah kepucatan & Kenyal & 0,67 \\
\hline B4 & Rifampisin 5 mg selama 7 hari & Merah kepucatan & Kenyal & 0,65 \\
\hline $\mathrm{C} 1$ & Rifampisin $8 \mathrm{mg}$ selama 10 hari & Merah kecoklatan & Kenyal & 0,79 \\
\hline $\mathrm{C} 2$ & Rifampisin 8 mg selama 10 hari & Merah kecoklatan & Kenyal & 0,94 \\
\hline C3 & Rifampisin $8 \mathrm{mg}$ selama 10 hari & Merah kecoklatan & Kenyal & 0,83 \\
\hline $\mathrm{C} 4$ & Rifampisin $8 \mathrm{mg}$ selama 10 hari & Merah kecoklatan & Kenyal & 1,09 \\
\hline
\end{tabular}


diakibatkan oleh iskemia ginjal juga disebabkan oleh obat-obatan yang bersifat toksik pada ginjal. Cedera akut tubular akan menyebabkan nekrosis, dan paling sering mengakibatkan gagal ginjal akut. Obat rifampisin yang diberi dalam dosis tinggi dapat bersifat toksik pada ginjal sehingga menyebabkan kerusakan ginjal. Rifampisin dosis 600 mg/hari pada manusia dapat menyebabkan efek samping terhadap ginjal berupa insufiensi ginjal, gagal ginjal akut, dan pengeluaran urin yang berwarna oranye-kemerahan. ${ }^{3}$

Berdasarkan hasil penelitian ini, pada ginjal tikus putih (Wistar) yang diberikan rifampisin dengan dosis $5 \mathrm{mg}$ selama 7 hari menunjukkan adanya vakuola-vakuola di dalam sel-sel tubulus dan ginjal tikus putih (Wistar) yang diberikan rifampisin dengan dosis $8 \mathrm{mg}$ selama 10 hari ditemukan adanya ciri-ciri mikroskopik nekrosis tubular akut, tetapi nekrosis yang terjadi pada kelompok rifampisin dosis $8 \mathrm{mg}$ hanya sedikit.

Perubahan morfologi pada cedera sel yaitu hilangnya polaritas sel merupakan kejadian awal yang penting secara fungsional (reversibel) sehingga menyebabkan pembengkakan sel. Hal ini menyebabkan redistribusi protein membran $\left(\mathrm{Na}^{+}, \mathrm{K}^{+}\right.$, ATPase) dari permukaan basolateral ke permukaan luminal sel tubulus sehingga penyaluran natrium ke tubulus distal meningkat, melalui sistem umpan balik tubuloglomerulus, menyebabkan vasokontriksi. Kerusakan lebih lanjut di tubulus dan terbentuknya debris tubulus dapat menghambat aliran keluar urin dan akhirnya meningkatkan tekanan intratubular sehingga GFR meningkat. ${ }^{3}$

Nekrosis tubular akut (NTA) adalah terjadinya destruksi sel epitel tubulus dan secara klinis ditandai oleh supresi akut fungsi ginjal. Nekrosis tubular akut akibat toksik obat-obatan dapat mengakibatkan penurunan perfusi ginjal, kenaikan sekresi $\mathrm{ADH}$ dan aldosteron serta kenaikan reabsorbsi natrium di tubuli proksimal. Mekanisme ini terjadi untuk mempertahankan volume intravaskuler dengan mencegah kehilangan natrium dan air dalam urin. Umpan balik dari tubuloglomerular adalah proses yang menyebabkan perubahan aliran glomerular pada nekrosis tubular yaitu reabsorbsi natrium klorida $(\mathrm{NaCl})$ yang tidak adekuat dalam tubulus proksimal yang rusak, menyebabkan peningkatan $\mathrm{NaCl}$ ke tubulus distal. Peningkatan $\mathrm{NaCl}$ dalam tubulus ginjal dapat mempengaruhi makula densa dan sebaliknya makula densa menyebabkan konstriksi arteriol aferen yang nantinya akan berpengaruh pada glomerulus. Pada tubulus akan ditemukan adanya cedera sel disertai vakuolisasi dan sel radang berkelompok padat pada vasa rekta sebagai respon terhadap adanya sel nekrosis. Jika hal ini terjadi maka sel-sel tubulus akan hancur dan menempel pada banyak nefron sehingga urin tidak dapat dikeluarkan karena nefron tersumbat. ${ }^{3}$

Efek dari rifampisin tampaknya menjadi faktor risiko yang signifikan untuk perkembangan gagal ginjal akut. Efek toksisitas rifampisin paling umum terjadi adalah nyeri perut, mual, muntah, dan flu. Tanda dari adanya kerusakan pada nekrosis tubular akut akibat rifampisin adalah terjadinya destruksi sel epitel tubulus. ${ }^{6}$

\section{SIMPULAN}

Berdasarkan hasil penelitian yang diperoleh dapat disimpulkan bahwa ginjal tikus putih yang diberikan rifampisin 5 mg/hari selama 7 hari menunjukkan adanya vakuola-vakuola di dalam sel-sel tubulus, sedangkan yang diberikan rifampisin 8 $\mathrm{mg} /$ hari selama 10 hari memiliki gambaran hitologis yang sesuai dengan nekrosis tubular akut.

\section{DAFTAR PUSTAKA}

1. Masters SB, Trevor AJ, Katzung BG. 2005. Katzung \& Trevor's pharmacology. New York: Lange Medical Books/McGraw Hill, Medical Pub. Division.120:123.

2. Sensi P. Rifomycin, a new antibioticpreliminary report. Farmaco Ed Sci. 1959;14:146-147. 
3. Contran RS, Rennke Hm Kumar V. Dalam: Kumar, Contran, Robbins. Buku ajar Patologi (Edisi Ketujuh). Jakarta: Penerbit Buku Kedokteran EGC, 2007; p.571-608.

4. Stricker $\mathbf{C H}$. Drug induced hepatic injury. Amsterdam: Elsevier Science PubI; 1985.
5. Dutt AK. Short Course Chemotherapy. The Arkansas experience. Chest. 1981; p. 80-727.

6. Rossert JA, Fischer EA. Acute interstitial nephritis. In: Johnson RJ, Feehally J, eds. Comprehensive Clinical Nephrology. 2nd ed. New York, NY: Mosby; 2003: 769-791. 